\title{
АНАЛІЗ ЦИВІЛЬНОГО ЗАКОНОДАВСТВА УКРАЇНИ ЩОДО ЗДІЙСНЕННЯ ТРАНСПОРТНИХ ПЕРЕВЕЗЕНЬ
}

\section{НАКОНЕЧНА Тетяна Василівна - асистент кафедри юриспруденції Чернівецького інституту Міжнародного гуманітарного університету}

DOI:10.32782/EP.2020.1.24

\begin{abstract}
У статті надається загальна характеристика належного правового регулювання транспортних перевезень, яке зумовлено необхідністю створення механізму правового регулювання транспортних відносин з урахуванням взаємовідносин Европейського Союзу та України у сбері транспортної політики, під иас інтеграчиї України до ЄС. Визначено, що за законодавством Украӥни договори про перевезення транспортом належать, за своєю суттю, до консенсуальних договорів, при иъьому порядок укладення вказаного договору перевезення відрізняються за певною специбікою, яка полягає в належності вищевказаних договорів до публічних. Акцентовано увагу на Законодавчу базу організащиї транспортних перевезень.

Ключові слова: договір перевезення, залізничний транспорт, повітряний транспорт, морсъкий транспорт, автомобільний транспорт, пасажир, вантаж, багаж, пошта
\end{abstract}

\section{Постановка проблеми}

Український уряд вживає дієвих заходів щодо покращення правового становища у державі, у зв'язку з чим, з урахуванням досвіду іноземних держав у нашій державі проводяться реформи у всіх галузях. Ці реформи направлені на покращення соціально-економічного, а також правового стану в державі шляхом уніфікації норм та положень різних інститутів права, зокрема таких елементів інституту цивільного права - транспортного та договірного права. Вивчення питань регулювання договірних правовідносин щодо здійснення перевезень на транспорті, хоч і неодноразово розглядалось, і нині є актуальним.

Аналіз останніх досліджень і публікацій

Теоретичну основу дослідження склали наукові праці таких правознавців, як: О. Красавчикова, В. Хропанюка, М.І Брагінського, В.В. Вітрянського, О.В. Дзери, О. Отраднової, Є.О. Харитонова, І.В. Жилінкової, Ф.С. Хейфеца, Н.Д. Шестакової, Е. Грамацького, В.І Гостюка, I. Калаура, В. Кучера, І.В. Матвеева, І. Спасібо-Фатєевої, М.В. Шульги, В.І. Павлова, А.М. Асаула та інших.

\section{Мета статті}

Метою статті $€$ науковий аналіз, систематизація, оцінка, розробка пріоритетних напрямів цивільного права в галузі договірного та транспортного права, а саме: правове регулювання договорів перевезення транспортом, підстав для зміни або розірвання укладених договорів перевезення та відповідальність сторін за невиконання або неналежне виконання умов договору перевезення, теоретичних та практичних проблем, що виникають у сфері цивільних правовідносин щодо договорів перевезення.

\section{Викладення основного матеріалу}

Однією з важливих категорій у цивільному законодавстві України є належне правове регулювання перевезень вантажів, 


\section{Цивільне, підприсмницьке, господарське та трудове право}

багажу, вантажобагажу пасажирів і пошти, законодавче регулювання порядку укладання та припинення договорів про здійснення перевезень, а також регулювання відповідальність сторін за договором перевезення вантажу, пасажирів, багажу та пошти.

Взаємовідносини Европейського Союзу та України у сфері транспортної політики, під час інтеграції України до EC, у зв’язку 3 великим зовнішньоторгівельним оборотом України з країнами СС, зумовлює необхідність у створенні чіткого механізму правового регулювання транспортних відносин. Однак, незважаючи на проведення кодифікації цивільного законодавства України, певні питання та проблеми перевезень на в повній мірі не врегульовані, тому практичне вирішення цих питань, які виникають у ході застосування та виконання вимог договорів про здійснення перевезень вантажів, пасажирів, багажу і пошти на транспорті (автомобільному, залізничному, морському, повітряному тощо), стикається 3 рядом питань щодо регулювання відносин у цій сфері.

Так, на залізниці, морські і річкові порти, аеропорти та інші транспортні організації покладено певні обов'язки, і одним 3 них є забезпечення потреб громадян як України, так і інших країн, зокрема країн євросоюзу, у транспортних перевезеннях та безпеки використання транспорту (залізничного, автомобільного, повітряного, річкового або морського тощо), для здійснення перевезення пасажирів, вантажу, пошти і багажу на транспорті. Перевізні правовідносини врегульовані главою 64 ЦК України, де, крім традиційних договорів перевезення вантажу (ст. 909 ЦК України) і пасажира (ст. 910 ЦК України), згадуються й договори, що опосередковують перевезення: договір чартеру (фрахтування) (ст. 912 ЦК України); угоди між організаціями різних видів транспорту щодо здійснення перевезень у прямому змішаному сполученні (ст. 913 ЦК України); договір перевезення транспортом загального користування (ст. 915 ЦК України); довгостроковий договір (спрямований на організацію перевезень) (ст. 914 ЦК України) [2].

Европейське транспортне право грає надзвичайно важливу роль для вдосконалення Українського транспортного зако- нодавства та встановленню відносин щодо транспортних перевезень. Договірні відносини Української держави з країнами - членами EG у транспортній сфері вимагають адаптації законодавства України до міжнародно-правових актів, які регламентують діяльність у сфері транспортних перевезень, зокрема перевезень пасажирів, вантажу, пошти і багажу транспортом у єдиній транспортній системі України.

У зарубіжній доктрині країн СС транспортні перевезення сприймаються як сфера сервісу, тобто діяльність щодо надання послуг по перевезенню вантажів та пасажирів транспортом. Крім того, транспорт, за сприйняттям країн $\mathrm{EC}$, також виступає засобом пересування, що належить фізичним або юридичним особам на праві власності.

Таким чином, транспорт як різновид сервісу підпадає під дію принципів спільного ринку EС, що гарантують свободу діяльності фізичним і юридичним особам на всій території Евросоюзу. При цьому EC у сфері транспортної інтеграції визначає загальні правила міждержавних транспортних перевезень, формує умови надання транспортних послуг перевізникам-нерезидентам у країнах $\mathrm{EC}$, визначає заходи транспортної безпеки, а також визначає ліцензійний порядок надання транспортних послуг. Вказане і є основою транспортної політики країн EC.

Регулювання транспортної політики в EC здійснюеться договором про функціонування EC. У цьому договорі скасовується будь-яка дискримінація щодо порядку транспортних перевезень та встановлення єдиних тарифів на перевезення територією Евросоюзу (п. 1 ст. 95) , звертається особлива увага на ефективність перевезень, дотримання порядку перевезень великих вантажів, на профілактику та зменшення транспортної аварійності, належне забезпечення розгалуженої системи транспортних шляхів та зменшення шкідливого впливу на зовнішнє середовище (Директива 99/94/EC) [5].

Транспортна політика EC, як і транспортна політика України на шляху до євроінтеграції, базується на принципах гармонізації й лібералізації. За допомогою 
встановлення єдиних правил діяльності у сфері перевезень, вносяться відповідні зміни щодо вдосконалення транспортного законодавства України.

Створення єдиного економічного простору на території країн СС передбачає наявність «єдиного» ринку транспортних послуг. Після підписання та вступу у силу єдиного європейського акту розвиток транспортної політики та лібералізація транспорту проходять інтенсивніше. Так, у червні 2001 року під час засідання європейської ради $\mathrm{EC} \mathrm{у} \mathrm{Ге-}$ теборзі, була прийнята до врахування та реалізації європейська транспортна політика - «Біла книга». У подальшому, Европейська Комісія внесла зміни до європейської транспортної політика та зробила акцентовану увагу на загальні для всіх країн ЄС підходи і спільний діалог з проблем транспорту та вирішення цих проблем шляхом розвитку галузі, створили план розвитку, розрахований на виконання до 2020 року. При цьому, Европейська Комісія вперше поставила потреби споживачів у центр своєї стратегії.

В Україні організація перевезень вантажу, пасажирів та багажу встановлюється: Правилами перевезення пасажирів, багажу, вантажобагажу і пошта залізничним транспортом України [12], Правилами перевезень вантажів автомобільним транспортом в Україні [13], Правилами надання послуг пасажирського автомобільного перевезення [14], Правилами повітряних перевезень пасажирів і багажу [15], Повітряним кодексом України [7], Статутом залізниць України [10], Кодексом торгового мореплавства України [8] тощо.

Таким чином, виконання договорів перевезень транспортом - це регламентований законодавством порядок і процес вчинення учасниками вказаних договорів послідовних та необхідних дій, які були обумовлені у договорі перевезення або транспортній накладній. Згідно 3 визначенням перевізник не зможе виконати свій обов'язок, що полягає у перевезенні вантажу, якщо відправник вантажу не надасть вантаж для перевезення у визначений строк, передбачений у договорі, а одержувач вантажу, у свою чергу, не зможе його одержати, якщо перевізник не поінформує його про прибуття вантажу.
Тому для відносин договору перевезення вантажу має велике значення вимога його належного виконання.

За договором перевезення транспортом пасажирів одна сторона (перевізник) приймає на себе зобов'язання щодо перевезення іншої сторони (пасажира) до місця призначення, а в разі наявності багажу, доставити й його до пункту призначення, де зобов'язаний видати його особі, яка має право його одержати. При цьому особа відправник та/або пасажир зобов'язуються сплатити встановлену плату за перевезення та проїзд [12, 13, 14, 15]. Договір перевезення залізничним, повітряним, морським або річковим та автопасажирським транспортом посвідчується квитком, багажною квитанцією, які надаються пасажиру, та транспортною накладною для перевезення вантажів.

Якщо звернутись до транспортного сектору EC то побачимо, що він є частиною спільного міжнародного ринку, який, у рамках транспортної політики EC, регулюється встановленими Европейським парламентом та радою, спеціальними нормами. Вказані норми, спільно 3 положеннями розділу VI частини третьої Договору про функціонування EC є джерелами формування у системі права EC інституту транспортного права. У цілому регулювання діяльності у галузі транспорту в Европі визначається нормами традиційних міжнародних договорів (Бернські вантажні конвенції 1966 року (КОТІФ), Монреальська конвенція 1999 року, Угода про міжнародне залізничне вантажне сполучення 1998 року (СМГС), з подальшим доповненням (МТТ) тощо).

I все ж на Українську державу покладається завдання забезпечити дію принципів спільного ринку стосовно залізничного транспорту. EС уніфікує моделі управління для єдиної системи транспорту. Держави члени EC та разом з ними й Україна на шляху до євроінтеграції самостійно розвивають мережі транспортних сполучень і забезпечують дотримання стандартів безпеки транспортними підприємствами. Під вказаними підприємствами розуміються будь-які підприємства (державні або приватні), які мають ліцензію, видану відповідно до законодавства ЕС. Основною діяльністю таких під- 


\section{Цивільне, підприсмницьке, господарське та трудове право}

приємств є надання послуг щодо транспортування товарів і (або) пасажирів транспортними засобами. Фундаментальні тенденції розвитку в галузі правового регулювання транспортного сектору в Україні полягають в усуненні всіх бар'єрів при перевезеннях у межах єдиної території. Це можливо лише завдяки цілеспрямованій і ефективній політиці України. Основними напрямами політики України у сфері транспорту є створення єдиної системи управління перевезеннями, комунікаційними та інформаційними мережами, загальних методів експлуатації та технічного утримання транспортних засобів, уніфікованих тарифів на перевезення тощо. Як приклад, звернемо увагу, що згідно «Сценарію залізничного бізнесу 2020 року» 3 часом EС зможе об'єднати 30 країн. При цьому, очікується, що до 2020 року обсяг пасажирських та вантажних перевезень зросте. Зазначені результати можуть бути досягнуті при виконанні наступних умов:

1) перевезення вантажів та пасажирів при мінімальній тривалості;

2) збільшення пропускної спроможності транспортних сполучень;

3) залучення та ефективне використання інвестицій;

4) більш високий ступінь безпеки;

5) скорочення енергоспоживання;

6) інтероперабельність, сутність якої по^ягає у створенні та забезпеченні умов для експлуатаційної та технічної інтеграції різних транспортних систем;

7) розробка законів, стандартів, правил, спрямованих на створення єдиних документів, що регулюють діяльність транспортних організацій та підприємств.

Таким чином, можна констатувати, що в області транспорту уніфікація права проявляється як за допомогою реалізації методу гармонізації, так і шляхом створення уніфікованих норм цивільного права.

Отже, транспортний комплекс - це великий сектор народного господарства, що забезпечує потреби економіки країни та населення у перевезеннях різними видами транспорту. Тому вдосконалення внутрішньодержавного, а також міждержавного регулювання діяльності транспорту - найваж- ливіший напрям проведення економічних реформ.

За законодавством України, договори про перевезення транспортом належать, за своєю суттю, до консенсуальних договорів, при цьому порядок укладення вказаного договору перевезення має деякі відрізнення за певною специфікою, яка полягає в належності вищевказаних договорів до публічних. Таким чином, транспортні підприємства повині та зобов'язані розпочинати договірні відносини з фізичними або юридичними особами щодо виконання перевезень на загальних умовах однакових для всіх сторін договору перевезення.

Отже, вказані вище зобов'язання транспортних організацій та/або підприємств мають організаційно-забезпечувальний характер та регламентуються законодавством [16].

Крім того, законодавством України визначені питання щодо організації контролю за перевезеннями транспортом, які також викладені у підвідомчих актах, які регламентують діяльність транспортних підприємств та організацій та встановлюють правила поведінки та дій учасників перевезень.

\section{Аітература}

1. Конституція України: станом на 1 верес. 2016 р.: відповідає офіц. тексту. Харків: Право, 2016. 82 с.

2. Цивільний кодекс України: Закон України від 16.01.2003 р. Відомості Верховной Ради Украӥни. 2003. № 45-46. Ст. 356.

3. Цивільний кодекс України: наук.практ. комент. (пояснення, тлумачення, рекомендації з використанням позиції вищих судових інстанцій, Міністерства юстиції, науковців, фахівців) / за ред. І. В. СпасибоФатєєвої. Харків, 2010. Т. 1: Загальні положення. 320 с.

4. Цивільний процесуальний кодекс України: Закон України від 18.03.2004 р. № 1618-IV. Відомості Верховної Ради України. 2004. № 40-41, 42. Ст. 492.

5. Про автомобільний транспорт : Закон України від 5 квітня 2001 року // Відомості Верховної Ради України, - 2001. -№ 22. - Ст. 105. 
6. Про транспорт: Закон України від 10 листопада 1994 року із змінами внесеними Законом від 21.12.2000 р. // Відомості Верховної Ради, - 2001, № 9, Ст. 68.

7. Повітряний кодекс України: Закон України від 04.05.1993p.// Відомості Верховної Ради 1993. - № 25.- Ст. 274.

8. Кодекс торговельного мореплавства України № 176/95-ВР від 23.05.1995. // Відомості Верховної Ради, 1995, №№ 47, 48, 49, 50, 51, 52, ст.349.

9. Директива Ради EС від 14 лютого 1994 року № 94/4/СС, що вносить поправки до Директив 69/169/ EЕС та 77/388/ EЕС та підвищує рівень податкових пільг для подорожуючих з третіх країн та обмежень на неоподатковувані покупки під час подорожей в межах Співтовариства // Европейський Союз; Директива, Міжнародний документ від 14.02.1994 № 94/4/GC. // URL: http:// zakon2.rada.gov.ua/laws/show/994_438

10. Статут залізниць України: затверджений Постановою Кабінету Міністрів України від 06.04.1998 № 457 // Офіційний вісник України. - 1998. - № 14.

11. Бродовський С.О. Деякі питанні укладення, зміни і розірвання договору в цивільному праві України. Юридична Україна. 2005. № 1. С.23-26.

12. Правила перевезення пасажирів, багажу, вантажобагажу і пошта залізничним транспортом України, затверджені наказом Міністерства транспорту і зв'язку України від 27 грудня в 2006 р. № 1196, зі змінами і доповненнями по 25 січня 2013 р. № $44 / /$ URL: http://vokzal-simferopol.info/uk/pravilaperevozki-passazhirov/

13. Правила перевезень вантажів автомобільним транспортом в Україні, затверджені наказом Міністерства транспорту України від 14 жовтня 1997 року № 363. // URL: $\quad$ http://search.ligazakon.ua/l_doc2.nsf/ link1/REG2568.html

14. Правила надання послуг пасажирського автомобільного перевезення, затверджені Постановою КМ України від 18.02.1997 p. № 176 // URL: http://search. ligazakon.ua/l_doc2.nsf/link1/KP970176.html
15. Правила повітряних перевезень пасажирів і багажу, затверджені наказом Мiністерства інфраструктури України від 30 листопада 2012 року № 735 // URL: https:// www.flyuia.com/ua/ua/information/rules-andregulations/carriage-rules

16. Цивільне право України: підручник: у 2 т. / за ред. Є. О. Харитонова, Н. Ю. Голубєвої. Харків: ТОВ «Одіссей», 2008. Т. 1.832 c.

Analysis of the civil legislation of Ukraine on the implementation of transport. Article

The article provides a General description of the proper legal regulation of transport, which is due to the need to create a mechanism of legal regulation of transport relations, taking into account the relations between the European Union and Ukraine in the field of transport policy, during the integration of Ukraine into the EU. It is determined that under the legislation of Ukraine, the transport contracts are, in essence, to consensual contracts, the order of the conclusion of the said contract of carriage has some differences in a certain specificity, which is the membership of the above agreements to the public.

Highlighted that Ukraine has a transportation is established: the Rules of carriage of passengers, baggage, cargo and mail by railway transport of Ukraine, Rules of transportation of cargoes by motor transport in Ukraine, the Rules of provision of passenger road transport, Rules of air carriage of passengers and baggage, the Air code of Ukraine, the Charter of Railways of Ukraine, the Code of trade navigation of Ukraine and the like. It is proved that the implementation of transport contracts - is regulated by the law and the process of committing parties to these contracts of consistent and necessary actions that were stipulated in the contract of carriage or bill of lading.

Therefore, the improvement of domestic and interstate regulation of transport is the most important direction of economic reforms.

Keywords: contract of carriage, railway transport, air transport, sea transport, road transport, passenger, cargo, Luggage, mail. 